\title{
Epistemology of Legal Studies Based on Revelation (Perspective of Legal Studies Development in Indonesia)
}

\author{
Yogi Prasetyo ${ }^{1}$, Khudzaifah Dimyati ${ }^{2}$ \\ Postgraduate of Legal Studies, Universitas Muhammadiyyah Surakarta, Indonesia ${ }^{1,2}$ \\ $\left\{\right.$ yogi_prasetyorais@yahoo.co.id ${ }^{1}$, kd255@ums.ac.id $\left.{ }^{2}\right\}$
}

\begin{abstract}
Conflicts and truth claims that occur between the epistemology of normative law science based on rational logic with the epistemology of legal sociology based on the reality of empirical law in society resulted in the science of law in Indonesia is not developing positively or can be said to have stagnated. Therefore, it is necessary to reform the epistemology of jurisprudence from other discourse, as found in a natural law based on religious revelation which touches on the substantial aspect of the spiritual-moral values of human beings as God's creatures. Basic use of epistemology of science based on revelation by the development of the era that is experiencing a multi-dimensional crisis due to the wrong way of thinking of the man himself, because it has disregarded the role of God in arranging the life of the world. The science of prophetic law based on religious revelation emerges as an exponent of a new paradigm in law science in Indonesia that carries important ideas about humanization, liberation, and transcendence.
\end{abstract}

Keywords: Epistemology, Legal Studies, Revelation

\section{Introduction}

Besides the senses, mind, and conscience as the basis of the epistemology of jurisprudence, in Indonesia, people also understand the revelation in the form of religion and scripture as a source of law recently. This is by the reality that the majority of the Indonesian population is Muslim, so the revelation (al-Quran) becomes part of the law to regulate the life of the community. Making revelation as the basis of law epistemology that can be used in general is not easy, because there is an objective and subjective perspective in it, so it is susceptible to certain sentiments that are deliberate or not become a separate problem in life. Law thoughts based on religion are in line with the postmodern era that is being a wave of changes in human civilization [1]. The incompetence of human in regulating life finally restores the various problems that exist to God the Almighty over everything [2]. The absoluteness of God's law that is often refracted by the postulates of manmade law shows its truth. As it has been explained in the revelation that God knows something best for the people, so it has become a necessity that human must believe and piety to Him [3]. The existence and benefit of revelation-based law have become the study of ontology and axiology law in Indonesia, whereas the revelation-based law as an epistemology of law can be understood by a certain methodology which suits its characteristics and peculiarities in order not to lose the basic principle of the value contained in it and also acceptable. This is different from what is meant 
in the Islamic law praxis (sharia)that has been formalized in Indonesia to organize certain things for the Muslim population [4]. However, the term of jurisprudence epistemology based on revelation takes the values or meaning contained in the revelation (Al-Quran) as the basis of common jurisprudence epistemology (general) that can be accepted in general.

The science of law based on revelation in Indonesia can be seen from the science of prophetic law which has three important values as its basic principle, namely humanization, liberation, and transcendence as its pillars. According to Kuntowijoyo, transcendence taken from the understanding of Al-Quran Surah Al Imran verse 110 is the basis of humanization and liberation in the epistemology of prophetic law. The dominance and role of religious revelation (al-Quran) as the value of transcendence in the prophetic jurisprudence is very strong when it is associated with elements of humanization and liberation. The prophetic jurisprudence based on revelation is studied by jurists in Indonesia such as (Koesnoe, Heddy Shri Ahimsa Putra, Amin Abdullah, Jawahir Thantowi, Syamsudin and Bambang Sutiyoso), in their writings mentioned about the object of prophetic law, namely all human activities that occur in life and also the usefulness of studying the jurisprudence that comes from God [5]. The prophetic jurisprudence is also expressed by (Absori, Kelik Wardiono, and Saepul Rochman), the science of prophetic law is presented as an alternative legal science, besides being theological, it tries to give critical correction to the existing law, especially normative positivistic [6]. There is also a criticism of jurisprudence that is not supported by a religious bases, such as criticism of non-systematic law. So that the prophetic jurisprudence appears more firmly with the main base of the revelation of Al-Qur'an, furthermore, the epistemology of prophetic jurisprudence is specifically discussed by Kelik Wardiono by using the concept of Kuntowijoyo; in his view Al-Qur'an is a revelation that can be transformed into the jurisprudence. The need to understand the Divine values whose truths can be objectified and explained scientifically [7].If tracing the prophetic jurisprudence based on revelation (alQuran) in Indonesia, it has inspiration from Islamic thoughts abroad, such as; Danah Zohar and Ian Marshal on the importance of spiritual intelligence [8], M. Abed al-Jabiri about bayani-burhani-irfani as a typical Islamic reason in Arab [9], and Syed Muhammad Naquib alAttas about the Islamization of science [[10]].

The main prophetic jurisprudence based on the Qur'an with the concept of humanization, liberation, and transcendence should make the human as a good servant of God, which means having an attitude of unity to a strong God. As described in Al-Quran Surah al-Fatihah verses $1-7$;

"In the name Allah, the most gracious, the most merciful. Praise be to Allah, the Lord of the Worlds. The most gracious again the most merciful. The master of the day of vengeance. Only You are the one we worship, and only to You, we ask for help. Point us up a straight path. That is the way of those whom You have given them a favor; Not their way of wrath and not their way of being astray ".

The man has been created by God as the perfect and best being; then the man should have achieved the good thing by trying and praying to God. With faith and devotion to God, man will receive the guidance of righteousness, a path that does not contain sin and mistake. Suggesting that religious duties might be ontologically superior to personal conclusions about right and wrong [11]. All is the will of God; man is obliged to obey and submit to the provisions of God that have been described in Al-Qur'an. The goodness of the earth happens because people follow the laws of God and the damage on earth happens because people violate God's laws. 


\section{Result and discussion}

Jurisprudence epistemology based on revelation has the same understanding with the law of nature theory or Nature law. The basic reason for the use of the law of nature theory is that philosophically Nature law has aspects of ontology law that comes from God, not the law in the sense of empirical understanding in society nor the law in a formal logical norm system. The epistemology that is often manifested in the form of reasoning method used the law of nature is not reached by mind reasoning methods and objective empirical, thus having more closeness to the irrational method in the principle of religious values. The use of revelation as a true source of knowledge in the law has been felt by humans from ancient times until now, although it is recognized that there is a need for transformative development. The difficult law issues resolved in the realm of empirical law and the positive norm system can be decomposed and resolved with the religious values contained in the revelation.

The object of the epistemology of the study of revelation-based law has similarities to the description in the theory of natural law, as described in the previous theory. Revelation as the basis of philosophical epistemology of jurisprudence is included in the study of natural law theory. It can be understood by ontology aspects of natural law theory that has a law object in the form of revelation of scripture that contains the religious values. Revelation regulates all areas of human life so that almost all legal issues that occurred can be studied by the truth of revelation. Epistemologically clear that revelation as the source of law derived from God and the conscience, morals, and sense becomes the specific characteristic of natural law theory. Natural law understanding law beyond the empiric and rational range prove that there is a greater source of law and has unmatched value. To reinforce it, the intuition of conscience even and moral still cannot touch it, although the reasoning of conscience has a closeness with God, but not all things can be understood by the human, even about conscience, namely the absolute truth of God's revelation. The axiological aspect of natural law theory also has role and usefulness similarities of revelation in human life, i.e., as guidance of life for a human to carry out the command and stay away from God's prohibition [12].

The theory of natural law as the oldest law theory has an ability that never been immersed in the development era and global modernity that the stronger waves hit the human life. The ability to survive from the natural law is inseparable from the base of faithful epistemological to support it all the time. Epistemology based-God's revelation on the natural law gets a strategic position in playing its role as the highest source of law and has the absolute value truth. Although in its development, the natural law has basic moral epistemology, conscience, and sense, so that the natural law becomes law concepts which cover various legal theories. Revelation as the source of natural law is believed to be able to serve all law problems and its development in human life. It can be seen when the senses and minds cannot understand the truth well, and the conscience has been distracted by strong interest so that the ultimate truth of God appears as the only grip for a human that does not need to doubted and verified. Such an understanding as proposed by AlbericusGentilis, he stated that to the natural law as a law that has structurally higher position becomes the basis of the policy of a king in the past. Positive law formed by the kings is an incarnation of natural law and should not be contrary to natural law.

Nature is a manifestation of God's existence in a real context. Nature law understands the law formed from God's creation as the ruler of the universe that produces endless and absolute justice. The nature law as God's justice is the highest level of law that cannot be reached by human ability. This understanding is suitable to the theory of modern natural law which patterned theology as proposed by the natural law theory of neo-scholastic flow by Le Fur. He 
describes that the concept of natural law is important which relates to the idea of God's justice as a natural law that relies on the human position as the best creation whose desire and higher intelligence, namely God intelligence [13]. God as the source of law is described in the revelation in the form of the holy book as the guidance of human life. The spiritual dimension in the social and legal study which associated to capitalism spirit has also been described by Max Weber through the "Protestant ethic" whose main point that hard work is a necessity to achieve spiritual welfare [14].

Thomas Aquinas in the middle-ages states that natural law is understood as the law comes from God. Moreover, he mentioned that there are four kinds of natural law [15]. First, Iexaeterna or eternal law, it is a form of God's power that cannot be captured by human ability. Secondly, Iexlivina or divine law, it is specific guidance from God on how people should live as it is written in the scriptures. Thirdly, Iex naturalism or natural law, the law is the most basic public instruction in human life, for example, a good thing must be done, whereas bad thing must be abandoned. This law is the embodiment of Iexaeterna into human ability. Fourth, lex positivism or applicable law, it consists of the positive law made by God which is found in the holy books and man-made positive laws. The positive law is an implementation of natural law based on specific requirements needed in the world [16]. According to Thomas Aquinas, there are two main principles in natural law, namely primary and secondary principle. Primary principle is the principle associated with the basic human right which is universal without limitation and time and attached to every human being. While the secondary principle is specific principles described from the primary principle by using the human mind. The enforcement and binding of the secondary principle are based on the policy established and given by the country's positive law. The enforcement and binding of the secondary principle are based on the policy established and provided by the country's positive law. In the elaboration of these secondary principles often occur irregularities and abuses committed by humans towards the law for a particular interest.

Revelation as the base of epistemology in legal studies, there are some Islamic jurists, such as Thomas Aquinas in the western and al Syafi'i in the eastern, who understand that the law derived from the revelation of God in the form of the holy book of the Quran. According to Syafi' $i$, based on the Islam religion, the natural law is the revelation of God delivered through the Prophet Muhammad for his people. The main source of law in Islam is Al Quran and Hadis which contains some guidance of life reflected from the life of the Prophet Muhammad. Islamic law sourced on the Al Quran is another form of natural law. Al Quran has a close relationship with God directly as the absolute authority-holder of the revelation, so the truth is guaranteed and no doubt or tested again. Shafi'i states that the law must be adapted to the will of God through the revelation of the Qur'an. Islam as a religion of revelation is a form of human recognition to believe, convince and completely surrender to God because God has established the law for people to manage life to be better.

Revelation as the basis of epistemology in legal studies has the object of all legal issues related to revelation as a source of law, such as holy book and Sunnah in Islam. Because of revelation as a source of external law of people, so that its existence can influence other internal people source of sense, mind, and conscience. Many kinds of legal issues related to religion's education in carrying out justification assessment become the object of revelationbased jurisprudence. Object of this jurisprudence will emerge when happens inappropriate in understanding the truth of law, so that the object of jurisprudence based sense, mind, conscience can metamorphose to be revelation-based jurisprudence. The globalization era and emerging several of conflicts are being legal issues, not only contravening the legislation and social system of society and hurting the conscience but also ignoring the God's role in 
arranging human life. It can be seen in some legal cases, such as the cases of student abuse by her teacher, religious conflict, simultaneous corruption conducted by some officers and various other cases [17].

Revelation as the review object of epistemology in legal studies is not only about the understanding of law as the social reality of society and law as the system of positive norms and law sense of conscience, but also it continues in taking the object of law into revelation based on the value of religion's education enclosed in holy book and sunnah rosul. Studying the law with revelation epistemology to a certain law case is not enough by looking at the empirical evidence of law and legislation and sense of conscience. Furthermore, the case of law will be assessed by using standard measurement coming from the transformation of the revelation value in religion's education, so that it is gotten a truth of revelation-based jurisprudence. The reason for doing the legal issue either intentional or unintentional gives impact to others. Therefore, the legal issue is understood totally to find out the real truth, the absolute truth of God. Understanding the object of law can reinforce specific character from the reasoning of revelation in the epistemology of law study.

The object of revelation-based law has conformity to reasoning method in natural law theory - this statement as described by Thomas Aquinas who understands God as the source of law. The revelation as the source of law has had the absolute and endless truth because it sources on God who controls everything. Based on the understanding and belief, the truth of revelation can be developed into scientific knowledge and having responsibility. The main revelation in the form of the holy book has had absolute truth so that legal problems can be examined by using the value of absolute truth. The scope of revelation object can arrange all aspects of human life; it makes people difficult to understand the object. Here, it is caused the inability of man in transforming revelation into the human understanding whose limit ability [18].

The epistemology legal study of revelation-based used secondary data in the form of a holy book and sunnah rosul gotten from literature. However, primary data obtained from the society directly and the study of conscience and moral of law is needed to complete the study of revelation. The use of these data is a consequence of the revelation-based unlimited epistemology in rational logic in reason and reality of empiric facts. All these data were used together to understand the legal issues faced. The use of these data was expected that the understanding of the law could bring the people into the absolute understanding of law and uncontested through some revelation-based hypothesis. It should be remembered that the use of primary and secondary data as well as data contains the study of conscience doesn't mean merging or integration of mind, senses, and conscience as in the legal theory of integral law (law integration). The data were only used to build construction of new data which capable of transforming the value of religion's education into human reason.

There are three techniques in collecting data to capture legal study of revelation-based. The first technique was conducting literature study through reading, watching, listening and writing all documents in the library and searching all documents on the internet. Second, exploring all information about law growing in the society by interviewing, observing, delivering questionnaire as in epistemology of sense-based jurisprudence relies on empirical data in the field. Third, contemplating to have a sense of conscience in law, this can be obtained from empirical reality in the society and legislation. The data must be proven by adapting other data. The validity of data needs to be examined critically and carefully before applied on the advance law study since the data obtained are complex and reached to several legal issues that have various backgrounds. The processing of primary data, i.e. legal reality in the society, the system of positive norms as the secondary data and the data explored from the 
conscience were conducted to get validated and organized data. The primary, secondary and obtained data from the study of conscience were conducted in this research as the processing data technique.

Moreover, the next step was classifying the data based on the classification of law materials and arranging the systematic data objectively and logically. The use of system arranged objectively and logically considered religion's education becomes the main principle in revelation-based jurisprudence and can be found in the method of reasoning of natural law theory. Revelation-based reasoning was done to analyzing process toward the relationship of one legal entity to others to achieve the understanding of law generally so that it is appropriate to the value of religion's education in the revelation. Although, the technique of processing data was conducted by having procedure and mechanism, i.e. deductive and inductive reasoning methods, the dimension of legal assessment standard should be believed and convinced well before explained scientifically. However, it does not mean that the resulting truth of the epistemology of revelation-based jurisprudence cannot be accepted and assured. Nowadays a lot of study findings admit the truth of revelation than objectively and rationally truth. After collecting and processing the data, then it was analyzed by reviewing the result of processing data supported by the theory of natural law that is more likely to have a common epistemological revelation-based. Analysis data is an activity providing supported review, opposing or giving justification for legal issues and ended by concluding seemly to the values of revelation in religion's education.

The epistemology study of revelation-based has higher reasoning than epistemology of sense-based, brain-based, and conscience-based. Reasoning methods of sense, brain, and intuition to revelation is used after having belief and faith of the truth. The senses, brain, and conscience only play as instruments to prove the truths that have been believed and convinced or called hypothesis. The truth obtained by revelation-based epistemology is the absolute or the real truth because it comes directly from God. In a certain time, there are legal issues that cannot be handled by the senses, mind, and human conscience, so that the revelation is needed to understand the truth. Revelation as the base of epistemology has an important role since it can affect the epistemological base of the senses, mind, and conscience. The values of religion's education in revelation can be the main orientation of truth created by senses, mind, and conscience, as in Islam, revelation is understood as word view of Islam as the basic in all aspects of human life. This understanding as argued by al -Jabiri about trilogy of Islamic reasoning methods: first, Bayani as the epistemology emphasizing on the authority of directly and indirectly text through inference (istidlal); second, Burhani as the epistemology creating knowledge through the basic principle of logic based on the previous believed-knowledge axiomatically (badhihi). Burhani is defined as a t hinking activity to decide the truth of proposition (qadliyah) through deductive approach (al-istintaj); third, Irfani as the epistemology based on the experience of conscience intuition as a method of knowledge expression obtained through exposure of God to his servant after having mentally and spiritually (riyadlah).

The use of inference method to sum up deductively as in logic reasoning caused the position of the main value of natural law of revelation-based epistemology on the lower level. The understanding was started from the conformity of the reality of empirical behavior to the system of positive law norms. The next step was examining the conformity of the system of positive law norm to the value of universally law truth obtained from the value of religion's education of revelation. It can be seen that the process of exploration the truth of law did not cease on the mind, but it was ended by higher reasoning method than mind as the source of the law. The natural law has two main reasoning methods used to comprehend the law truth. First, 
on the highest level has the absolute belief and confidence to God written in Al Quran and explained more in Al Hadis. Second, on the lower level has inference by concluding deductively or inductively. It is not reliable of reasoning method in understanding natural law, as argued by Shidarta and Khudzaifah Dimyati.

The epistemology legal study of revelation-based has an important role in human life. Based on the absolute and real benefit, epistemology legal study of revelation-based has an advantage, they are: first, as the highest level of the source of law that it can be used as the main and principal basic for the lower law. Second, it is the solution of legal issues for the most difficult problems which cannot be solved by the human because of limited human ability. Third, by having belief and confidence, it can be used to draw hypothesis to describe more about the truth through epistemology of senses, mind, and conscience. Fourth, a revelation in the form of a holy book can be used directly and indirectly to be positive law. Fifth, religiously, the use of revelation as the source of law is a form of human faith and devotion to God (tauhid), so there is a relationship between law and religion, and next, it is used as the main framework in developing integral legal study or integrated law and religion [19].

\section{Conclusion}

In the effort to explore and obtain a good legal science is not enough just to base on the science of normative law in the legislation and legal sociology contained in the empirical reality of law in society, but also required epistemology of science based on God's revelation contained in the scriptures and values -the value of religious teachings. Legal science thus, the value of truth contained in it is not only recognized by rational logic and empirical reality but also can be recognized truthfully and eternally. Epistemology of God-based law of revelation as in the science of prophetic law has the dimension of humanization, liberation, and tridentidity that can guide and guide people to achieve a better and ultimate life. The epistemology of the science of revelation-based law shows the position of the human race as the best of God's creation.

\section{References}

[1] M. B. Patrick, "The Liberty of the Church: Source, Scope and Scandal," J. Contemp Leg. Issues, vol. 21, no. 165, pp. 189-193, 2013.

[2] S. P. Michael, "The Priority of God: A Theory of Religious Liberty," Law Rev., vol. 39, no. 1159, p. 1160, 2013.

[3] S. Micah, "Religion, Equality, And Public Reason," Bost. Univ. Law Rev., vol. 94, no. 1321, p. 1336, 2014.

[4] J. Greg, "Innovation, Arbitrage, and Ethics: The Role of Lawyers in the Development of a New Transnational Islamic Finance Law," Georgetown Law J., vol. 104, no. 1345 , pp. 1346-1348, 2016.

[5] Syamsudin, Ed., Ilmu Hukum Profetik. Yogyakarta: Universitas Islam Indonesia, 2013.

[6] K. W. Absori and R. Sepul, Hukum Profetik; Kritik Terhadap Paradigma Hukum Non-Sistematik. Yogyakarta: Genta Publishing, 2015.

[7] K. Wardiono, Paradigma Profetik: Pembaruan Basis Epistemologi Ilmu Hukum. Yogyakarta: Genta Publishing, 2016.

[8] Z. Danah and M. Ian, Spiritual Intelligence The Ultimate Intelligence. London: 
Bloomsbury, 2000.

[9] A. A.-J. Muhammad, Bunyah al 'Aql al 'Arabi; Struktur Nalar Arab, Markaz Dirasah al Wihdah al Arabiyah. Beirut: Libanon, 1986.

[10] M. N. A.-A. Syed, Islam, Secularism and the Philosophy of the Future, vol. 3. London-New York: Mansell Publishing Limited, 1985.

[11] W. M. Michael, "Why Protect Religious Freedom?," Yale Law J., vol. 123, no. 770, p. 792, 2013.

[12] L. Cécile, "Dworkin's Freedom Of Religion Without God," Bost. Univ. Law Rev., vol. 94, no. 1255, pp. 1258-1271, 2014.

[13] W. Friedmann, Legal Theory. London: Stevens \& Sons Limited, 1953.

[14] M. Weber, The Protestan Ethic and The Spirit of Capitalism. London, 1992.

[15] A. Thomas, Summa Theologiae, Terj. R.J. Henle, vol. 1. University of Notre Dame Press, 1985.

[16] T. Huijbers, Hukum Dalam Lintasan Sejarah. Yogyakarta: Kanisius, 2008.

[17] C. M. Linda, "Can Religion Without God Lead To Religious Liberty Without Conflict," Bost. Univ. Law Rev., vol. Vol 94, no. 1273, pp. 1300-1319, 2014.

[18] C. Erwin and G. Michele, "Religion Is Not A Basis For Harming Others," Georg. Law Journal., vol. 104, no. 1111, p. 1135, 2016.

[19] W. Jeremy, "Religion Without God By Ronald Dworkin," Bost. Univ. Law Rev., vol. 94, no. 1207, pp. 1207-1211, 2014. 